\title{
EDITORIAL
}

\section{Publishing in predatory journals: Time for reflections}

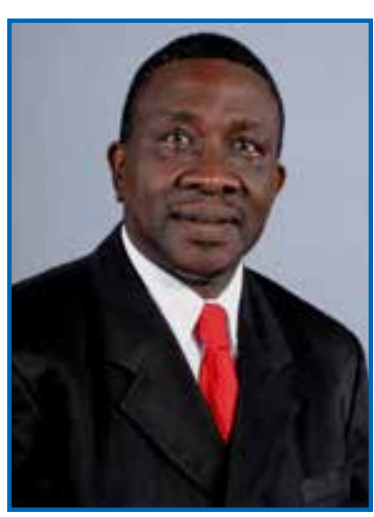

A predatory journal is an online academic journal that charges people money to publish their article, but without the services such as peer review or editing that usually warrant the money. Jeffrey Beall, a University of Colorado Denver associate professor and librarian, and creator of 'Beall's List of Potential, Possible, or Probable Predatory Scholarly Open-access Publishers' has led a crusade against journals referred to as predatory journals, which were "of questionable and downright low quality". In 2012, he described predatory journals as "counterfeit journals to exploit the open-access model in which the author pays. These predatory publishers are dishonest and lack transparency."1,2

In January 2015, he compiled a list of "Criteria for Determining Predatory Open-Access Publishers". The criteria recognised two documents published by the Committee on Publication Ethics (COPE) namely Code of Conduct for Journal Publishers Principles of Transparency and Best Practice in Scholarly Publishing. ${ }^{3}$ Under the criteria for editor and staff, he identified the following: The publisher's owner is identified as the editor of each and every journal published by the organization; no single individual is identified as any specific journal's editor; the journal does not identify a formal editorial/review board and no academic information is provided regarding the editor, editorial staff, and/or review board members (e.g., institutional affiliation), to mention a few. ${ }^{3}$ However, he closed down his website in January 2017 without any explanation. There was speculation that he was forced to do so by his university that feared possible legal action from 'predatory' publishers.

In 2015, Shen C and Björk BC investigated the extent of predatory publishing between 2010 and 2014. They estimated that the journals they identified as predatory (using Beall's list and criteria) had increased their output from about 53000 articles in 2010 to an estimated 420000 in 2014. Authors paid an average "article processing charge" of US\$178 per article typically published within 2 to 3 months of submission. In terms of authors' locations, who published in predatory journals, India topped the list with $34.7 \%$, followed by the rest of Asia (25.6\%) and Africa (16.4\%) respectively. ${ }^{4}$

Within the South African context, two academics from the Centre for Research on Evaluation, Science and Technology, namely Johann Mouton and Astrid Valentine, reported that between 2005 and 2014, more than a quarter of the research output at three universities ended up in bogus journals. ${ }^{5}$ It is estimated that the Department of Higher Education and Training (DHET) paid 100-300 million rands in academic subsidies for articles published in predatory journals for more than a decade. ${ }^{1}$ DHET pays a university about R100,000 for each qualifying academic article, which has to be published in a journal accredited by the DHET. A number of questions as follows need answers:

a. Why does the DHET accredit predatory journals for research subsidy purpose?

b. Why do authors from South African universities publish in predatory journals?

DHET has access to check the predatory journals on 'Beall's List of Potential, Possible, or Probable Predatory Scholarly Openaccess Publishers'. It is unclear why these journals are still maintained on their database of subsidy journals. In the case of authors, the reasons are multi-factorial ranging from pressure to publish by universities, academic promotions linked to research output, financial incentives to publish and competition among institutions in terms of research rankings, to mention a few. Whatever the reasons to publish in predatory journals, this cannot be justified as it is an "unethical" practice. Emphasis should not be on incentives to publish but to reward publications in accredited, peer-reviewed scientific journals, and if necessary. In addition, academics who publish in predatory journals should be informed and possibly sanctioned to stop such practices as these affect the academic integrity of their institutions. To stem the tide of publication in predatory journals, DHET should no longer accredit predatory journals on their database and universities should update their research policies to discourage submission of articles to predatory journals by its academics. The latter will send a strong message for researchers to boycott predatory journals and will set South Africa on an upward trajectory of research excellence.

\section{Prof. Gboyega A Ogunbanjo}

Editor-in-chief: SAFPJ

\section{References:}

1. Wild S. Predatory journals: government loses millions to articles in journals that swindle. Business Day 19 Sept 2017. Available at https://www. businesslive.co.za/bd/national/science-and-environment/201709-19-predatory-journals-government-loses-millions-to-articles-injournals-that-swindle/

2. Beall J. Criteria for Determining Predatory Open-Access Publishers. http://beallslist.weebly.com/uploads/3/0/9/5/30958339/criteria-2015.pdf

3. Wild S. GUIDE: How to spot predatory academic journals in the wild. Africa Check. Available at https://africacheck.org/factsheets/guidehow-to-spot-predatory-academic-journals-in-the-wild/

4. Shen C, Björk BC. 'Predatory' open access: a longitudinal study of article volumes and market characteristics. BMC Medicine. 201513:230.

5. Mouton J, Valentine A. Predator alert! Credible science is being gobbled up, warn academics. Times Live. 03 August 2017. Available at https:/ www.timeslive.co.za/news/sci-tech/2017-08-03-predator-alert-credible-science-is-being-gobbled-up-warn-academics/ 